\title{
Barış Eğitiminin Teorik Zemininde Felsefenin Önemï
}

$\ddot{O} z$

Küresel anlamda yaşanan savaş, çatışma ve ayrımcılık gibi durumlar insanlığın geleceği adına kaygı verici boyutlardadır. Gelecek nesillere barışçl bir dünya emanet edebilmenin yolu barış eğitiminin önemsenmesinden geçmektedir. Ancak barıș eğitiminin okul müfredatlarında yer almasından önce dersin teorik yapısı hususunda belirsizliklerin olduğu dikkat çekmektedir. Söz konusu belirsizliğe istinaden bu çalışmada, barış eğitiminin teorik yapısının oluşumunda felsefeden hangi kazanımların sağlanabileceği tartışılmaktadır. Bu çerçevede öncelikle insani anlamda barış eğitiminin niçin önemsenmesi gerektiği ele alınmaktadır; ikinci adım da ise filozofların barıșın sağlanması hususunda ileri sürdükleri bazı teorilerine yer verilmektedir. Üçüncü adımda ise bu düşüncelerden barış eğitimi adına hangi kazanımların elde edilebileceği irdelenmektedir. Özellikle akıl-barış ilişkisi, insan hakları ve barışın mutlak bir değer olarak görülmesi anlayışı söz konusu eğitimin teorik yapısının teşekkülünde başvurulacak değerler olarak karşımıza çıkmaktadır. Son tahlilde ise mevcut analizler üzerinden bazı tespit ve önerilere ulaşılmaya çalışılmaktadır.

Anahtar Kelimeler: Barış, Eğitim, Teorik Zemin, Felsefe, Akı1.

\section{The Significance of Philosophy on the Theoretical Ground of Peace Education}

\begin{abstract}
The problems of war, conflict, discrimination which were suffered globally are in the level of concern for the future of the humanity. The way of leaving a legacy of peaceful world to the following generations may be possible to attache importance to peace education. The ambiguities about theoretical background of peace education draw attention before it is placed on the schools' curriculums as a lesson. This work discuss how philosohpy contribute to establish the theoretical body of peace education against the said ambiguities. In this framework, firstly, it is addressed why it is necessary to give importance to peace education; Secondly, some theories which were argued by philosophers for peacebuilding are articulated. Thirthly, it is analysed what sort of acquisitions from those thoughts on behalf of peace education. Particularly the relationship of intelligence-peace, human rights and the understanding of adoption of peace as an absolute value come out as values so as to establish the theoretical body of the mentioned education. In conclusion, it is tried to provide some deductions and suggestions through the current analyses.
\end{abstract}

Keywords: Peace, Education, Theoretical Ground, Philosophy, Intelligence.

\footnotetext{
${ }^{*}$ Bu çalışma 17.F1214.02.02 kodlu GÜBAP projesi kapsamında hazırlanmıştır.
} 


\section{Giriş}

Tarih boyunca yaşanan çatışma ve savaşlar nedeniyle barış, insanlığın temel arayışlardan başında gelmektedir. Bununla birlikte geçen yüzyıldan günümüze değin ileri teknolojinin savaş teçhizatında kullanılması nedeniyle savaşların ortaya çıkarabileceği tahribatlar tahayyül edilemeyecek derecededir. Habermas'a göre ABC silahları olarak ifade edilen atom, biyolojik ve kimyasal silahların ekonomik güç savaşlarına dönüşmesinden dolayı dünyanın siyasal durumu insan varoluşunu tehdit altına almaktadır (Habermas 1996: 24). Söz konusu silahlar ve bunların değişik türleri seri üretim sayesinde küresel anlamda ekonomik gücü elinde bulunduran ülkelerin temel ticari metaları haline dönüşmesini, insanlık adına trajik bir durum olarak nitelendirmek gerekmektedir. Ayrıca küresel güçlerin başka ülkelere yönelik ekonomik savaşları insan hayatına yönelik tehditlerin şiddetini artırmaktadır.

Bununla birlikte Afrika'da her gün yirmi dört bin kişinin sadece açlık ve açlığa yakın nedenlerle, yedi yüz civarında kadının ise sağlık imkânlarının yokluğundan dolayı doğum sırasında hayatını kaybettiği tespit edilmiştir (Emin 2016: 1-11). Aynı zamanda yoksulluk, işsizlik, tecrit ve tehdit gibi olumsuz hayat şartları nedeniyle birçok insan doğup büyüdüğü yeri terk etmek zorunda kalarak, kendisi ve ailesinin geçimini temin edebilmek için yeni arayışlar içine girmektedirler. Akdeniz'de alabora olan botlarda hayatını kaybeden insanlar ve kıyılara vuran cesetler insani anlamda vicdanları yaralamaktadır (Yeşilçayır 2016: 122). Diğer taraftan ülkemizin içinde yer aldığ coğrafyanın çatışmacı/savaşçı yapısının endişe verici boyutlarda olduğu görülmektedir. Ayrıca kavga ve şiddetin günlük hayatımızda, spor müsabakalarında, sokakta ve okulda, sıklıkla karşılaşılan bir durum olduğu yadsınamaz bir gerçektir. Bunun yanında din, etnik köken, mezhep, kıyafet ve cinsiyet aidiyeti nedeniyle ötekileştirme ve dışlanma gibi sorunlar günlük hayatımızın bir parçası haline gelmiş durumdadır. Dolayısıyla yaşadığımız dünyanın barışçı olduğunu iddia etmek pek mümkün değildir.

Küresel anlamda yaşanan şiddet, çatışma ve savaşlar uzmanları bazı endişelere sevk etmiş olacak ki, eğitim alanında söz konusu sorunları önleyici mahiyette bazı önlemlerin alınmasına ilişkin tutumların gelişmeye başladığı görülmektedir. $\mathrm{Bu}$ çerçevede özellikle Batılı ülkelerde barış eğitimine yönelik ilginin artarak ortaya çıkabilecek olası şiddet, çatışma ve anlaşmazlıkları önceden önleyici pedagojik anlayışın benimsenmesini gelecek adına umut verici olarak nitelendirmek mümkündür. Barış eğitimi konusunda ülkemizde de başlangıç seviyesinde gelişmeler kaydedildiği ve konunun entelektüel/akademik anlamda tartışılmaya başlandığı görülmektedir (Aslan, Karaman Kepenekci, Karagül, Doğan Güldenoğlu 2016: 10 vd). Ancak barış eğitiminin 
okullarda nasıl uygulanması gerektiği ve bu bağlamda kullanılabilecek teorilerin belirsizliği dikkat çekmektedir. İnsan hayatında barışı tesis etmek gibi böylesine anlamlı bir misyonu üstlenen bir eğitim anlayışında teorik zeminin inşası oldukça önemli bir yere sahiptir. Söz konusu eksiklik ve belirsizliğe istinaden elinizdeki çalışma barış eğitiminin teorik yapısının oluşmasında felsefenin sunabileceği katkıları ele almayı amaçlamaktadır. Bu bağlamda düşünce tarihi boyunca barışın tesisi adına ortaya çıkmış teorilerden barış eğitimi adına hangi kazanımların elde edilebileceğinin irdelenmesi gerekmektedir. Çalışmamızın ilk adımında barış eğitiminin birlikte yaşamak bağlamındaki önemi irdelenecektir. İkinci adımda felsefe tarihinde ortaya çıkmış barış düşünceleri analiz edilmeye çalışılacaktır. Burada literatürde barış adına ortaya çıkmış bütün teorilere değinmekten ziyade, barış eğitimi adına kazanıma dönüşebilecek mahiyetteki düşünceler ele alınmaktadır. Üçüncü adımda ise ele alınan teoriler çerçevesinde barış eğitiminin teorisinde faydalanılabilecek olan unsurlar ve hangi türden bir kazanıma dönüşebilecekleri tartışılacaktır. Son tahlilde ise yer verilen analiz ve bulgular üzerinden birtakım tespitlere/önerilere ulaşılmaya çalışılacaktır.

\section{Barış Eğitiminin Önemi}

Felsefenin barış eğitimine sağlayabileceği katkıları tartışmaya geçmeden önce barış eğitiminin niçin önemsenmesi gerektiği ve bu konuda nasıl bir farkındalık yaratılabileceği hususu üzerinde durmamız yerinde olacaktır. Yaşadığımız dünyanın mezkûr gerçekleri göz önünde tutulduğunda bir taraftan dünya genelinde barış eğitimine yönelik ilgi artarken diğer taraftan kavga, şiddet ve savaş etkisini önemli ölçüde hissettirmektedir. Bu sorunu paradoksal bir durum olarak değerlendirmek mümkündür. Aynı zamanda şiddet ve kargaşa durumunun barış eğitimine yönelik ilgi ve gereksinimi doğurduğunu iddia edebiliriz. Buna göre özellikle Batı ülkelerinde yaygınlaşmaya başlayan barış eğitimini küresel anlamda yaşanan olumsuzlukları önleme çabası olarak değerlendirmemiz mümkündür. Söz gelimi Almanya'da barış eğitimi (Friedenserziehung) ve barış pedagojisi (Friedenspaedagogik) son yıllarda oldukça rağbet görerek okullarda ve halka yönelik eğitimlerde yaygınlaşmaya başlamıştır. Bu çerçevede savaş ve şiddetin insan aklından ortaya çıktığından dolayı, bu eylemleri önlemenin yine insan aklını eğitmekle mümkün olabileceği şeklinde bir prensip benimsenmektedir. ${ }^{1}$ Giriş bölümünde $\mathrm{ABC}$ silahlarının küresel anlamda nasıl bir güç mücadelesine dönüştüğüne, ekonomik savaşa ve açlıktan hayatını kaybeden insanlara değinmeye çalıştık. Yaşanan bu tür olumsuzlukların geleceğe yönelik azalmasında ve

\footnotetext{
${ }^{1}$ Daha fazla bilgi için: http://www.bpb.de/internationales/weltweit/innerstaatlichekonflikte/54765/bildungsarbeit-und-friedenserziehung, Erişim Tarihi: 15.08.18.
} 
ortadan kalkmasında barış eğitiminin yadsınamayacak derecede önemli olduğunu ifade etmemiz gerekmektedir.

Bununla birlikte günlük hayatta mütemadiyen kadınlara, çocuklara, hayvanlara ve doğaya yönelik uygulanan şiddet durumları ile karşılaşılmaktadır. Söz konusu sorunsal, barış eğitiminin ne kadar önemli bir gereksinim olduğuna ve bu eğitimin teorik zemininin oluşumunda insanın değerinin ihmal edilmemesi gerektiğine işaret etmektedir. Bu çerçevede eğitimcilerin barış eğitimi konusunda yeterli olup olmadıkları, öğretmen eğitiminde barış eğitimine önem verilip verilmediği ve ders kitaplarının içeriklerinde ötekileştirici/ayrımcı unsurların olup olmadığı hususları akıllara gelmektedir. Öyle ki Tarih Vakfi tarafından yürütülen "Ders Kitaplarında İnsan Hakları Projeleri” kapsamında kitaplarda birçok ayrımcı ve dışlayıcı ifadelerin olduğu tespit edilmiştir. ${ }^{2}$ Söz konusu ötekileştirici tutumların önemli bir bölümünü de toplumsal anlamda henüz tam anlamıyla tartışmaya başlamadığımızı da belirtmemiz gerekmektedir. Bu sorunların başında ise cinsiyet ayrımcılığı gelmektedir.

Eğer günümüzün genç nesilleri savaş, kavga, şiddet gibi kötü olarak nitelendirebileceğimiz tecrübeler ediniyorlarsa yaşadıkları tecrübeleri gelecek nesillere de aktarmaları ve bu şiddeti onlara uygulamalarının kaçınılmaz olduğu öngörülmektedir. Gelecek nesilleri bu kısır döngüden nasıl kurtarılması gerektiği üzerinde durulması ve sorunun çözümüne yönelik çalışmaların yapılması gerekmektedir.

Burada ifade etmeye çalıştığımız ve hepimizin malumu olduğu sorunlar barış eğitiminin ne kadar önemli ve elzem olduğuna işaret etmektedir. Çünkü barış eğitimi ortaya çıkabilecek olası çatışma, kavga ve anlaşmazlıkları önceden önleyici pedagojik bir tutum ve anlayışı içinde barındırmaktadır. Buna göre barış eğitimi suçu sonradan tespit edip suçluları cezalandırmaktan ziyade bireyleri bilinçlendirerek hak ihlallerini, şiddeti, kavgayı ve savaşları önceden önleyeceği bilgiyi ve becerileri onlara kazandırmayı amaçlamaktadır. Ancak içinde bulunduğumuz kavga ve şiddet durumu barış eğitiminin verimli olarak ifa edilmediğinin bir göstergesidir. Buna göre öncelikle barış ve eğitimi konusunda toplumsal olarak bilinçlenmeye ihtiyaç duyulduğu aşikârdır. $\mathrm{Bu}$ bilincin oluşması ise, siyaset, toplum, eğitim gibi alanların göstereceği ortak irade ve ortak çalışmalar ile mümkündür. Bunun sağlanması ile birlikte barış eğitimi adına daha sağlam adımlar atılabilir.

\footnotetext{
${ }^{2}$ http://egitimdeinsanhaklari.org/media/documents/08_05_2015_13_53_06237a.pdf, Erişim tarihi: 15.08.18.
} 


\section{Felsefe ve Barış}

Barış eğitiminin pedagojik bir tutum olmasının yanında politika ve felsefenin önemli rol oynaması gereken bir alan olarak düşünülmesi gerekmektedir. Öncelikle siyasi iradenin bu türden bir eğitimin oluşması yönünde bir irade göstermesi gerekmektedir. Felsefe ise barış eğitiminin teorik yapısının oluşmasında başvurulması gereken temel mecradır (Frieters-Reermann 2009: 21). Bu çerçevede felsefe ve barış eğitimi arasında kurmaya çalıştığımız ilişki bağlamında bazı noktaların üzerinde durmak gerekmektedir: Felsefi bağlamdaki bir analizde herhangi bir teorinin uygulanmak istenen pedagojik anlayışa birebir mutabakatından söz etmek çok doğru bir tutum olmayacaktır. Burada önemli olan düşünce tarihinin bir döneminde ortaya çıkmış bir teoriden içerik olarak nasıl bir kazanım elde edilebileceği hususudur. Söz gelimi bir düşüncenin özündeki temel prensibi anlamaya çalışmak, bunu modern bakış açısıyla analiz etmek, yorumlamak ve buradan hedeflenen alanla ilgili bir sentez oluşturmaya çalışmak belli bir teorinin inşasında önem arz etmektedir. Buna göre felsefi bir düşünceyi eğitim alanına doğrudan tekabül ettirmeye çalışmaktan ziyade, söz konusu fikrin ana ilkesinin hangi pedagojik kazanımlara evrilebileceği üzerinde durmak daha isabetli olacaktır. Konuyu düşünce tarihi bağlamında ele almanın en önemli getirisi ise geniş bir bakış açısı ile gözlem yapabilmektir.

İnsanlığın birlikte huzur içinde yaşayabilmesi için son derece önemli olan barış eğitiminin okullarda uygulanması konusunda faydalanabilecek teorik müfredatının eksikliği söz konusudur. Eğer bir ülkede barış eğitiminin etkili bir biçimde uygulanması ve bununla gelecek nesillerin barışçı olması hedefleniyorsa öncelikle belirli bir müfredata ve bunun teorik yapısına ihtiyaç duyulacaktır. Bu noktada düşünce tarihi içinde ortaya çıkmış barış teorilerinin incelenmesi ve barış eğitiminde ihtiyaç duyulan teorik zeminin oluşturması adına önemli bir kazanımların edinilmesi mümkündür. Düşünce tarihinde ortaya çıkmış barış teorileri irdelendiğinde dikkat çekici unsurların başında akıl gelmektedir. Öyle ki insan aklının hedeflenen barış durumuna yönelik ortak kullanımı ve bu hedefe yönelmek için elzem olan ortak iradenin/isteğin oluşması gerektiği savı birçok filozof tarafından önemsenmektedir. Bununla birlikte barışın tesisi hususunda en az akıl kadar önemli olan diğer bir husus ise, adalettir. Şu halde barışın yeşerip büyüyebileceği temel alanın adalet olduğuna dair teoriler önemli bir ağırlığa sahiptirler. Buna göre barışın sağlanması öncelikle adaletin sağlanması ile mümkün olabilecektir ve buradaki adalet konusunu insan haklarının sağlanması olarak düşünmek yerinde bir tutum olacaktır. Diğer taraftan barış felsefesi adına ortaya çıkmış teorilerde barışın mutlak bir değer olarak ele alınması gerektiği yönünde bir anlayışın 
yaygınlaştığı görülmektedir. Mezkûr hususları analiz etmeye ve buradan barış eğitimine nasıl bir yolun gidebileceğine yönelik bulgulara ulaşmaya çalışalım. Öncelikle düşünürlerin barışın tesisi ile akıl arasında kurdukları ilişkiyi ele alalım.

\section{Akıl ve Barış İlişkisisi}

Özü itibarıyla akıl felsefenin temel enstrümanıdır/argümanıdır ve filozoflar yaşadığımız dünyanın sorunlarına akıl temelli çözümler üretmeye çalışmışlardır. Özellikle de insan hayatının nasıl barışçı olması gerektiği ile ilgili akıl temelli teoriler düşünce tarihi boyunca ortaya atılmıştır. Örneğin Helenistik dönemde yaşayan Stoacılar evrensel akıl olarak tanımladıkları logostan bütün insanların eşit miktarda pay aldıklarını iddia etmişlerdir. Buna göre logostan eşit miktarda pay alan insanların kendi aralarındaki hür-köle, kadın-erkek, Grek-Pers, asil-avam gibi ayrımlar ise oldukça anlamsızdır. Böylelikle insanları, dünya toplumunun eşit yurttaşları olarak gören Stoacılar, yeryüzündeki sınırların da oldukça yersiz olduğuna inanıyorlardı (Tannenbaum, Schultz, 2013: 92). Rönesans döneminde yaşayan ve Avrupa'nın içinde bulunduğu savaş durumundan duyduğu rahatsızlığı eserlerinde dile getiren Erasmus ise akıllı bir varlık olarak insanın huzur ve barışa ulaşmak konusunda daha yetkin olması gerektiği savunuyordu. Ona göre akıl, insana diğer insanlarla dostane ilişkiler kurması için bahşedilmiştir. İnsanın bunun farkına vararak vahşi hayvanlar gibi savaşmayı bir tarafa birakarak aklının yolundan gitmesi gerekir (Erasmus, 2018: 28-32). Stoacılar ve Erasmus insan hayatının barış̧ı olabilmesi için önemine dikkat çekmeye çalı̧̧ıkları insan aklı, barışı tesis etmek konusunda Immanuel Kant'ta zirve yaptığını iddia edebiliriz. Onun teorisi genellikle akıl barışı olarak adlandırılmaktadır (Yeşilçayır, 2017: 110).

Kant, insanın aklının kullanmasının önemini 1784 yılında kaleme aldığı Aydinlanma Nedir Sorusuna Cevap? adlı yazısında ele alır. Ona göre aydınlanma insanın kendi aklını bir başkasına danışmadan kullanamamasından kurtulmasını ifade eder. Şu halde insanın aklını başkalarının etkisinden ve emrinden kurtararak kullanma cesaretini göstermesi gerekir (Kant, 1968/1: 35). Bununla birlikte Kant, Ebedi Barlş Üzerine Felsefi Bir Tasarım adlı eserinde insan hayatının barışçı olmasının yine insanın kendi elinde olduğunu ifade ederek insan aklının önemini vurgulamaktadır (Yeşilçayır, 2017: 108).

Tarih boyunca ortaya çıkan kavga, şiddet ve savaşlar insanların ego ve hırslarını tatmin edebilmek için başvurdukları bir yoldur. Hırs, kibir ve tutkularıyla hareket eden ülke yöneticileri insanların ölmesine, halkın açlık ve sefalete sürüklenmesine neden 
olmuşlardır (Kant, 1968/2: 351). Hâlbuki doğaları gereği hayvanlar, sözgelimi öküzün boynuza, aslanın pençeye sahip olması gibi, kendilerini koruyucu bazı özelliklere sahipken, bunun yerine insana akıl bahşedilmiştir. İnsana akıl verilmesinin temel nedeni ise aklını kullanarak hayatını idame ettirmesi ve diğer insanlarla barış içinde yaşamasıdır. İnsanı barışa götürecek yolun, onun aklını doğru kullanmasına bağlı olduğuna inanan Kant, bunun için tutku, hırs ve egodan uzak durmak gerektiğini ifade eder (Yeşilçayır, 2017: 108). Helenistik dönemde Stoacılar tarafından ortaya atılan akıl temelli barış düşüncesinin Yeniçağ'da Kant tarafından daha sistematik bir biçimde ele aldığını ifade etmemiz gerekmektedir. Dolayısıyla gerçek barış, yalnızca insanın aklını iyiye kullanarak barışı isteme iradesini göstermesi suretiyle ulaşılabilecek bir durumdur.

Kant'ın felsefesinde barış bir gelecek zaman kuramıdır ve bu hedefe ulaşmak ise reformlar yoluyla, aşamalı olarak mümkün olacaktır. Ona göre barışa yönelmek akıl sahibi olan insanın temel ödevlerinden biridir (Arendt, 2005: 352). Eğer insanlar bu ödev konusunda bilinçlenirlerse doğa da insanın bu amacına ulaşması için seferber olacaktır. Kökeni insan aklı olan ve insanlar/ülkeler arasında barışı hedefleyen bu kuramın gerçekleşmesi ise insanlığın bir ödevi olarak nitelendirilmektedir. Kant, kalıcı barış düşünesinin boş bir fikir değil, insanlığın bir ödevi olduğunu savunur ve bu konuda asıl ödev sahibi kurum olarak politikaya işaret eder (Kant, 1968/2: 386). Siyasi anlamda örgütlenerek barış konusunda toplumsal bir bilinçlenmenin sağlanması eğitime verilecek önem sayesinde mümkündür. Dolayısıyla Kant'ın barış durumunun oluşabilmesi için insan aklının iyiye kullanılması gerektiğine vurgu yapması ve bu bağlamda kalıcı dünya barışını sağlamanın insanlığın kendi elinde olduğunu vurgulaması oldukça özgün düşünceler olarak karşımıza çıkmaktadır. Sonraki yıllarda ve özellikle XX. Yüzyıl'da ortaya çıkan uluslararası organizasyonlar kapsamında Kant'ın düşüncelerine sıklıkla atıf yapılacaktır. Bununla birlikte onun barış teorisi bağlamında yer verdiği unsurlar bunlarla da sınırlı değildir. Düşünce tarihinde pek çok filozof barışın tesis edilmesinin yolunun adaletin/insan haklarının/hakkaniyetin sağlanmasından geçtiğini ileri süren filozoflar olagelmiştir ve Kant bu filozofların başında gelmektedir.

\section{Barış ve İnsan Hakları İlişkisi}

İnsan hayatının barışçı olmasının insanın aklını iyi anlamda kullanmasına bağlı olduğunu savunan filozofların sayısı yukarıda ifade edilenlerden çok daha fazladır. Aslında barış ve insan hakları arasında bir ilişkinin kurulması da aklın barış alanına yansımasının bir sonucu olarak görülmelidir. Bununla birlikte barış ve insan hakları arasında güçlü bir ilişki olduğunun düşünülmesi, negatif barış anlayışının pozitif barış 
anlayışına doğru evrilmesi ile başlayan bir sürece tekabül etmektedir. Negatif barış anlayışında barış, savaşın yokluğu olarak anlaşılmaktadır ve burada savaşın olmadığı durumdan insanların memnun olması gerektiğine dair bir anlam söz konusudur. Ancak felsefi bağlamda ele alındığında barışı salt, savaşın yokluğu olarak düşünmek, barışın teorik temellerinin oluşmasını güçleştireceğinden, oldukça yetersizdir. O halde barış1 savaşın yokluğundan daha fazla bir şey olarak ele almak gerekmektedir. Buna göre pozitif barış anlayışında temel olarak barışın şimdiye ve geleceğe yönelik bütün savaş faktörlerinin ortadan kalktığı bir durum olarak düşünülmesi gerekmektedir. Söz konusu sağlıklı barış durumunun oluşmasının temel koşulu ise adalet ve insan haklarının sağlanmasıdır. Kuçuradi'ye göre bütün yurttaşların temel insan haklarını dile getiren ilkeler eşit bir biçimde korunuyorsa bu durumu barış olarak nitelendirmek mümkündür (Kuçuradi 2016: 181).

İnsan hakları/adalet ile barış arasında kurulan ilişkiye felsefe tarihinden örnekleme ile açıklamaya çalışalım: Kant'ın barış teorisi akıl temelli bir anlayış olmasının yanında gerçekleşmesini öngördüğü adalet durumu ile yakından ilişkilidir. Bu süreç ülkeden başlayarak evrensele yayılan üç aşamalı hukuksal bir durumu gerektirir ve dünya yurttaşlığı hukuku ile nihai hedefine ulaşmış olur. Dünya yurttaşlığı hukuku devletlerin kapalı toplum olmaktan kurtulmasını ve herhangi bir hak ihlalinin dünyanın her yerinde hissedilmesine imkân sağlayacaktır (Kant, 1968/2: 386). Bu çerçevede dünya barışının sağlanmasında insanlar arasındaki dil, din, mezhep, bölge ve etnik kökene dayalı ayrımcılıkların ortadan kaldırılması gerekmektedir. Dolayısıyla Kant, akılcı bakış açısının bir yansıması olarak barışın sağlanmasının öncelikle insan haklarının/adaletin sağlanmasına bağlı olduğunun altını çizmek ister. Onun modern anlamdaki insan hakları anlayışının kuramsal temellerini attığı (Habermas 2010: 344) düşünüldüğünde, barış ve adalet arasında kurmaya çalıştığı ilişki daha anlaşılır olmaktadir.

Barışı adalet bağlamında temellendiren fillozofların ortaya koyduğu düşünceler barış eğitiminin teorik zeminin şekillenmesi adına önemli fikirler sunmaktadır. Buna göre her insanın yalnızca insan olmasından kaynaklanan doğal hakları vardır. Şu halde hak, belli bir hukuk sistemi tarafından insana bahşedilen bir şey olmaktan ziyade, yalnızca insan olmak ile ilgili bir durumdur. Bu bağlamda düşünüldüğünde barış hakkını insan haklarının bir türü olarak nitelendirmek mümkündür. Çotuksöken'e göre insan hakları akıl ve aydınlanma ile çeşitlenip, zenginleşmektedir. Bununla birlikte yaşama hakkı, barış hakkı ve sağlıklı bir çevrede yaşama hakkı insan haklarının çerçevesine girmektedir (Çotuksöken 2012: 98). $\mathrm{Bu}$ temellendirme üzerinden 
gidildiğinde insan haklarının yok sayıldığı yerlerde barışın hayata geçmesi de mümkün değildir. Böyle bir ortamda barıştan söz edilse de pozitif anlamdaki gerçek barış anlayışından uzak olacağından kırılgan bir yapıya sahip olacaktır. Yaşadığımız dünyada böyle bir manzara söz konusudur ve barışın sağlanamamasının en önemli nedeni insan hakları hususunda yaşanan ihlallerdir.

Savaşlar ve şiddet kültürü insanı etkisi altına almaktadır. Böyle bir insanlık durumuna felsefe açısından bakmak bizi daha iyi bir biçimde aydınlatabilir (Çotuksöken 2012: 102). Ceylan'a göre yerkürede var olan tüm beşeriyetin barış içinde yaşaması ancak insan merkezli bir eğitim anlayışı çerçevesinde sağlanabilir. Böyle bir dünya görüşünde dinsel, ulusal ve mahalli değerler yerine hümanist, evrensel değerler esastır (Ceylan 2010: 114). Bunun gerçekleşebilmesi insan hakları ve barış eğitimine gereken önemin verilmesi sayesinde mümkündür.

Söz konusu amacın gerçekleşebilmesi öncelikle insanların iyiyi, adaleti ve barışı istemesine bağlıdır. Bu tutumu ahlaki bir seferberlik ve insanlığın en büyük erdemi olarak nitelendirmek yerinde bir tutum olacaktır. Dolayısıyla insanlar arasında kalıcı barışın sağlanabilmesi için insan haklarının/adaletin sağlanması önem arz etmektedir ve bu türden bir anlayış bütün savaş faktörlerinin ortadan kaldırılmasını talep ettiğinden pozitif olarak adlandırılmaktadır. Barışın felsefi bağlamda temellendirilmesi hususunda filozofların üzerinde durduğu önemli bir husus ise barışa olan inancın tam ve barışın mutlak bir değer olarak düşünülmesi minvalindedir.

\section{Barışın Mutlak Bir Değer Olarak Düşünülmesi}

Barışı, ateşkes dönemlerine benzer bir biçimde yalnızca savaşın olmama hali olarak düşünen negatif anlayışın yerine, geniş bir bakış açısıyla ve geleceği de hesaba katan pozitif anlayışlar geleceğin daha barış̧̧ olması adına önemli bir muhtevaya sahiptir (Yeşilçayır, 2017: XIII). Buna göre barışı adalet ve insan hakları zemini üzerinde tesis etmenin yanında bütün savaş/kavga nedenlerini ortadan kaldırmaya yönelik bir bilincin oluşması önemlidir. Gelecek nesilleri savaşın neden olabileceği musibetlerden korumanın temel yolu da bu anlayışı eğitim yoluyla yaygınlaştırmaktan geçmektedir. Şüphesiz bu anlayışın yaygınlaşabilmesinin ilk adımı barışın sağlam ve kalıcı olması için çaba gösterecek iradedir. Kant'ın akılcı bakış bağlamda ileri sürdüğü temel prensip ise eğer insanlık barış istiyorsa öncelikle bunu gerçekleştirebilecek bir irade sergilemesi gerektiğidir. Diğer bir ifadeyle insanlığın barışçı bir dünyaya doğru evrilmesi aslında yine insanın kendi elindedir (Yeşilçayır 2017: 108). Görebildiğimiz kadarıyla başta Kant, olmak üzere filozofların barış hususunda üzerinde durmaya 
çalıştıkları diğer bir husus daha olduğu anlaşılmaktadır. Buna göre, insanlığın geleceğinin barış̧̧ olabilmesinin temel koşulu barışın mutlak bir değer olarak düşünülmesi ve barışı istemedeki kararlı tutumdur.

Şu halde insanlar ve toplumlar arasında yüzyıllardan beri süregelen savaş faktörlerinin birdenbire ortadan kalkması mümkün değildir. Bu nedenle hedeflenen barış durumuna yaklaşabilmenin yolu hedefe yönelik tedrici reformlar/çalışmalar yapmaktan geçmektedir. Bu süre zarfında barış durumuna yönelik kararlılıktan vazgeçilmemesi gerekmektedir. Kant, teorisinde barış durumuna giden yolun devrimden değil, aşamalı olarak yapılacak reformlarla mümkün olabileceği ve barış bilincinin sürekli olması gerektiği üzerinde durmaktadır (Yeşilçayır 2017: 83). Bu hedefe ulaşmak için Kant, devrimi değil status quonun reformlar yaparak aşamalı olarak iyileşmesini önerir. Ona göre akıl sahibi bir varlık olarak insan, barışı isteme ve bunu reformlarla gerçekleştirebilme kapasitesindedir. Aklın iyiye kullanılması savaşı mutlak bir biçimde ortadan kaldırarak, kalıcı barış durumunun oluşmasını sağlayacaktır (Arendt 2005: 352). Ayrıca Kant barışla ilgili kaleme aldığı eserinin son kısmında ebedi barış düşünesinin boş bir fikir olmadığını ifade eder. İnsanların barışa mutlak olarak inanması halinde gerçekleşmesi olanaklı bir gelecek zaman durumu olduğundan söz eder. Çünkü barış genellikle ateşkes dönemine benzer, savaşın yokluğu olarak düşünüldüğünden kalıcı olarak tesis edilememiştir. Kalıcı/sürekli barış ise boş bir fikir değildir, fakat bu duruma erişmek için mutlak bir inancın ve hedefe yönelik aşamalı reformların gerçekleştirilmesi gerekmektedir (Kant 1968/2: 386). Barış konusunda felsefi bağlamında ortaya çıkmış bu düşüncelerin barış eğitimi anlamında pedagojik bir kazanıma dönüştürülmesi mümkün ve elzem gözükmektedir.

Öncelikle ülke/dünya barışının bir hayal olduğu gerekçesiyle eğitiminin boş bir çaba olduğunu düşünerek, bu amaca yönelik barış eğitiminden vazgeçmemek gerekmektedir. Barış eğitimi bağlamında benimsenmesi gereken en önemli prensip, barış adına atılabilecek büyük, küçük bütün çabaları benimsemek ve bu amaca yönelik bütün imkânları değerlendirmektir. Bu prensibi başta toplumsal bir amaç haline getirmek önemli bir adım olacaktır. Barış eğitimine başlandığında karşılaşılan sorunlar, söz gelimi kavga ve şiddetin devam etmesi gibi, eğitimcileri/pedagogları hedeflerinden yıldırmaması gerekmektedir. Barışın sağlanmasına yönelik inancın mutlak olması ve hedefe yönelik çalışmaların mütemadiyen gerçekleştirilmesi gerekmektedir. Bu bağlamda eğitimcilerin metanetli ve sabırlı olmaları önem arz etmektedir ve öğretmen yetiştirme programlarının bu amaca yönelik düzenlenmesi gerekmektedir. Yirminci Yüzyll'da barış eğitiminin teorik zeminin oluşumunda Johan Galtung'un önemli 
atılımları olmuştur. Bu noktada onun düşüncelerine ayrı bir başlık olarak yer vermeye çalışalım.

\section{Galtung ve Barış Eğitimi}

Düşünce tarihi içinde barış adına ortaya çıkmış teorileri barış eğitimi adına önemli bir kazanıma dönüştürmeyi hedefleyen Norveçli düşünür Galtung 1959'da Oslo'da Uluslararası Barış Enstitüsünü kurmuştur (Galtung/Fischer 2013: 189). Kant'ın teorisine benzer biçimde Galtung, barışın bir durum olmaktan ziyade devamlılığı olan bir süreç olduğunu savunmaktadır. Buna göre bugün barışı sağlamak önemli bir adımdır, ancak gerçek anlamda barışın tesisi olası bütün çatışma/şiddet faktörlerinin bertaraf edilmesiyle mümkündür. Bununla birlikte barış durumunun iyileştirilerek ve sağlamlaştırılarak geleceğe taşınması ve sürdürülmesi gerekir. ${ }^{3}$

Galtung'ın barışla ilgili düşünceleri temel olarak negatif barış ile pozitif barış ayrımına dayanmaktadır. O, barışı yalnızca savaşın yokluğu olarak tanımlayan negatif barış anlayışından ayrılmaktadır. Buna göre barış çalışmalarının çatışma çözümlemelerinden ayrılarak pozitif barış bağlamında kendi başına bir disiplin haline getirilmesi gerekmektedir. Şu halde, barış konusunu belli normlar vasıtasıyla saldırgankurban çerçevesinde ele almak ve saldırganları cezalandırmak oldukça yetersizdir (Turanlı Yücel 2012: 19). Çünkü savaş, saldırgan-kurban, barış konularının üzerine daha fazla sorgulamalar yaparak konuyu bir eğitim ve kültür biçimi haline getirmek mümkündür. $\mathrm{Bu}$ bağlamda Galtung, barışla ilgili şu tanıma yer vermektedir: Barış "Savaşın yokluğu ya da askıya alınmasından ziyade pozitif bir iyi, korkunun yokluğu demek olan mutluluk halidir; farkl11ıkların kabulünden kaynaklanan bir huzur durumudur" (Galtung 1999: 153).

Galtung, Kant'ın ileri sürdüğü kalıcı barış anlayışını Yirminci Yüzyıl'da yeniden ele alarak, bu düşüncenin eğitim ve kültürel faaliyet biçimine dönüşmesine önemli katkılar yapmıştır. Buna göre kalıcı barışın sağlanması için bütün korku/şiddet faktörlerinin ortadan kalkması gerekmektedir. Onun çalışmaları toplumlarda oluşması gereken barış kültürü ve eğitiminin inşasına doğru evrilmektedir ve o, barış eğitiminin salt okullarda verilen bir dersle sınırlandırılmayıp kitle iletişim araçları vasıtasıyla toplumun geneline yayılmasını savunmaktadır.

\footnotetext{
${ }^{3}$ http://www.rpi-loccum.de/material/aufsaetze/theo_mokrosch, Erişim Tarihi 10.08.2018.
} 


\section{Sonuç ve Değerlendirme}

Barış konusuna felsefe nazarından bakmak ve barış teorilerini modern anlamda irdelemek oldukça ufuk açıcı fikirleri karşımıza çıkarmaktadır. Buna göre barış konusunda filozofların ortaya koyduğu teorilerin akademik anlamda sorgulanması barış eğitiminin ve kültürünün oluşmasına önemli katkılar sağlayabilecek mahiyettedir. Mutlak bir arayış içinde insan hakları ve evrensel ilkelere önem veren Kant gibi düşünürlerin fikirleri başta olmak üzere, felsefe tarihi barış eğitiminin teorik zemininin inşasında vazgeçilmez bir öneme sahiptir. Bununla birlikte barış eğitimi gelecek nesilleri savaş ve şiddetten korumayı hedefleyen pedagojik bir tutumu içinde barındırdığından pozitif hukukun sağlayabileceği yasallığa hapsedilemeyecek derecede önemlidir. Dolayısıyla barış ve eğitimi mevcut bir hukuk sisteminden ziyade insan hakları bağlamında ele alınması gereken bir anlayış olmalıdır. Yapmaya çalıştığımız analizler doğrultusunda felsefi bağlamda barış eğitiminin yaygınlaşabilmesi adına bir takım tespitlere/önerilere ulaşmak mümkündür:

\section{Barış hakkının temel bir insan hakk olarak benimsenmesinin önemi:}

Savaş ve şiddet yaşama hakkını tehdit eden temel faktörler olduklarından yaşama hakkı ile barış hakkı arasında doğrudan bir ilişki olduğunu ifade etmemiz mümkündür. Barışı korumak aynı zamanda yaşama hakkını korumak anlamına gelmektedir. Buna göre barış eğitimini insan hakları ve adaletten ayrı düşünmemek ve söz konusu eğitimin temelinde insan hakları bilincini yerleştirmek gerekmektedir. Bununla birlikte mevcut bilgi kirliliğinin aşılması, zihinlere yerleşmiş ön yargıların sorgulanarak yaşama ve barış hakkının temel insan hakları olduğunun farkına varılması ancak eğitim sayesinde mümkündür. Barış durumunu gelecek nesillere aktarmak için bu hedefe yönelik mutlak inanca ve iradeye gereksinim duyulmaktadır.

\section{Öğretmen ĕgitiminin yeniden yapılandırılması:}

Bununla birlikte barış konusunda bireylerin eğitilmesi hususunda iyi donanımlı eğitimcilere ihtiyaç olduğu anlaşılmaktadır. Eğitimcilerin şiddetin/çatışmanın devam ettiği durumlarda bile barışa yönelik inançlarını yitirmemeleri ve kalıcı barışın sağlanması hususunda sabırla çaba sarf etmeleri geleceği barışçıl kılmanın en önemli anahtarıdır. Böyle bir anlayışa sahip eğitimci/öğretmen başkalarının hakkına saygı duymanın yanında, insan hakları eğitimi hususunda azimli ve sabırlı bir kişi olmalıdır (Kuzgun 1981: 101-108). Söz konusu eğitimi gerçekleştirecek olan eğitimci, öğretmen ve pedagogların yetişmesi için de öğretmen yetiştiren yükseköğretim programlarının yeniden yapılandırılmasına ihtiyaç olduğu aşikârdır. 


\section{Felsefi aklın barış eğitiminde kazanıma dönüş̧ürülmesi:}

Barış eğitimi konusunda felsefi anlamda ortaya atılmış akıl ve adalet düşüncelerinden nasıl bir kazanım elde edilebilir? gibi bir soru akıllara gelebilir. Söz konusu eğitim sürecinde öğrencilere barışın sağlanması için emirler/yasaklar çerçevesinde bir eğitim verilmesinden ziyade, akla/mantığga dayalı bir pedagojik tutumun benimsenmesi ve bu süre zarfında adaletin elden birakılmaması önem arz etmektedir. Buna göre bireylere şiddete başvurma! Saldırma! Kavga etme! gibi emir ve yasaklar telkin etmek yerine onların niçin bu eylemlere girişmemesi gerektiği hususunda bilinçlendirilmesi gerekmektedir. Bununla birlikte bireylerin küçük yaşlardan itibaren başkalarının da kendileri gibi birer insan olduğu, insan onurunun ve haklarının dokunulmaz olduğu hususunda eğitilmeleri mezkûr/mevcut sorunların çözümünde önemli bir rol oynayacaktır. Aksi takdirde şiddet ve kavganın çözümden ziyade çözümsüzlük yaratan bir kısır döngüye yol açması kaçınılmazdır.

Barlş eğitimini bütün derslerin temel karakteristiği haline getirmek:

Okullarda barış eğitimi adı altında derslerin yer alması önemli bir gelişme olarak nitelendirilebilir. Ancak barış bilincinin geliştirilmesi adına barış eğitimini bütün derslerin temel karakteristiği haline getirmek daha etkili bir yöntem olacaktır. Bu çerçevede derslerde normatif bir anlayışla belli bir milleti, dini ya da mezhebi kutsallaştırıp anlatmak yerine daha çoğulcu ve insani tutumların benimsenmesi barış bilincinin gelişmesine katkı sağlayacak bir adımdır. Özellikle sosyal bilimler, tarih, edebiyat, sosyoloji ve felsefe gibi derslerin müfredatları insan hakları ve barış bilincinin yaygınlaştırılması bakımından uygundur.

\section{Ötekinin İnsani Anlamda Bir Kazanıma Dönüştürülmesi:}

Eğitimde öncelikle bireylerin temel insani değerlerle yetiştirilmelerinin hedeflenmesi barış bilincini gerçekleştirmek adına önemli bir adım olacaktır. Bu süreçte insan olmanın birincil hedef olarak belirlenmesi ve bireyleri ötekileştirmeyen ortak ölçütlerin geliştirilmesi ile ilişkili bir durumdur. Öyle ki insaniyet alanı her ferdin tek tek katılabileceği ortak bir alanı temsil ettiği için yaşamların ortaklık kurmasını, ortak ölçütler geliştirmesini gerektirmektedir. Buna göre insan olmak sen ve ben'den oluşsa da ancak bizlerle yürütülebilecek bir varoluş halidir. Öteki olmadan benin inşası ve tekâmülü mümkün değildir (Türer 2015: 374). O halde ancak birlikte ve beraberce insanlaşabiliriz. Farklılıkların ötekileştirilip dışlanması için değil, farklılıkların yaratıcı bir biçimde yönetilerek insan hakları ve toplumsal barış adına kazanımlara dönüştürülmesi önemsenmelidir. 


\section{Eğitimi Bir Insanlaşma Serüveni Olarak Düşünmek:}

Barışın sağlanması ve korunması bakımından "insan olmak" ve "insanlaşma" anlayışının ihmal edilmemesi gerekmektedir. Bireylerin belli bir meslek edinmelerinden önce insani anlamda iyi eğitilmeleri sağlanmalıdır. Buna göre bireylerin iyi bir doktor, iyi bir mühendis ve iyi bir öğretmen olmadan önce etik değerlerle yetişmiş iyi bir insan olarak yetişmesi önemsenmelidir. İyi insan olmayı öğrenmenin ve benimsemenin ilk adımı da insanın özü itibarıyla değerli olduğunu anlamaktan geçmektedir. Bu bağlamda kalıcı barışın sağlanmasının öncelikle insanı ve onun değerini anlamanın önemi ortaya çıkmaktadır.

İnsanlık durumlarında yaşanan hak ihlalleri ve barışın sağlanamaması insan aklının ürünüdür. Felsefe bize insan aklıyla çıkmış sorunların çözümünün yine insan aklı ile mümkün olduğunu önermektedir. Şu halde insanlığın içinde bulunduğu söz konusu olumsuz durumların olumlu olana doğru evrilmesi için öncelikle insanın aklını iyiye doğru yönlendirmesi gerekmektedir. Bunun en etkili olacağı alan ise eğitimdir; eğitimin insaniyetli, hakkaniyetli ve barışçıl olarak yeniden inşasında felsefeden önemli kazanımlar sağlamak mümkündür. Bununla birlikte insan haklarına ve evrensel barışın Batı kökenli fikirler oldukları yönündeki önyargıları bir kenara bırakıp, bu değerlerin eğitimine önem vermek gerekmektedir. Netice olarak barış eğitimini ortaya çıkabilecek olası çatışma, kavga ve anlaşmazlıkları önceden önleyici pedagojik bir anlayış olarak düşünmek yerinde olacaktır. Barış eğitiminin ve bilincinin yaygınlaştırılması ile birlikte gelecek adına güven duymak ve gelecek nesilleri savaş ve kargaşadan korumak mümkün olabilecektir.

\section{Kaynakça}

ASLAN, Canan, KARAMAN KEPENEKCİ, Yasemin, KARAGÜL Sedat ve Bilge Nur DOĞAN GÜLDENOĞLU (2016). Çocuk ve Gençlik Edebiyatında Gençlik Eğitimi, Ankara: Ankara Üniversitesi Yayınları.

ARENDT, Hannah (2005). "Kant'ın Siyaset Felsefesi Üzerine Notlar", çev. Yasemin Tezgiden. Cogito 41-42: 340-379.

CEYLAN, Yasin (2010). "Yirmibirinci Yüzyılda Eğitim Felsefesi Nasıl Olmalıdır?", 6-8 Mart 2009 Uluslararası Eğitim Felsefesi Kongresi, Bildiriler ve Tartısmalar, (Ed. Halil Rahman Açar). ss. 114-116, Ankara: Eğitim-Bir-Sen. 
Celal YEŞİLÇAYIR, “Barış Eğitiminin Teorik Zemininde Felsefenin Önemi”, Mavi Atlas, 6(Özel Sayı)/2018: 13-28.

ÇOTUKSÖKEN, Betül (2012). Insan Hakları ve Felsefe, İstanbul: Papatya Yayınları.

HABERMAS, Jürgen (1996). "Kants Idee des Ewigen Friedens-aus dem historischen Abstand von Zweihundert Jahren", Friden durch Recht, haz. Matthias Lutz-Bachmann \& James Bohman). ss. 7-24, Frankfurt am Main: Suhrkamp Verlag.

HABERMAS, Jürgen (2010). "Das Konzept der Menschenwürde und die realistische Utopie der Menschenrechte", Deutsche Zeitschrift für Philosophie, Akademie Verlag, 58(3): 343-357.

EMİN, Emin (2016). Küresel Adaletsizlik Dünya Yoksulluk ve Eşitsizlik Raporu, İstanbul: İnsamer.

ERASMUS (2018). Barışın Şikâyeti, çev. Celal Yeşilçayır. İstanbul: Dedalus Yayınları.

FRIETERS-REERMANN, Norbert (2009). Frieden lernen Friedens-und Konfliktpädagogik aus systemisch-konstruktivistischer Perspektive, Köln: WikuWissenschaftverlag.

GALTUNG, Johan (1999). Bir Başka Açıdan Insan Hakları, çev. Müge Sözen. İstanbul: Metis Yayıncılık.

GALTUNG, Johan ve Dietrich FISCHER (2013). Johan Galtung: Pioneer of Peace Research, Heidelberg: Springer Verlag.

KANT, Immanuel (1968/1). Beantwortung der Frage: Was ist Aufklärung? (1784), Akademie Textausgabe VIII, Berlin: Walter de Gruyter.

KANT, Immanuel (1968/2). Zum ewigen Frieden (1795), Akademie Textausgabe VIII, Berlin: Walter de Gruyter.

KUÇURADİ, İoanna (2016). İnsan Hakları: Kavramları ve Sorunları, Ankara: Türkiye Felsefe Kurumu.

KUZGUN, Yıldız (1981). “İnsan Hakları ve Eğitim”, A.Ü. Eğitim Fakültesi Dergisi 100 Yıla Armağan Sayısı:101-108.

TANNENBAUM, Donald ve David SCHULTZ (2013). Siyasi Düşünce Tarihi Filozoflar ve Fikirleri, çev. Fatih Demirci. Ankara: Adres Yayınları.

TURANLI Yücel, K. (2012). Barış Hakkı ve Hayata Geçirilmesi, İstanbul: On İki Levha Yayınları. 
Celal YEŞILLÇAYIR, “Barış Eğitiminin Teorik Zemininde Felsefenin Önemi”, Mavi Atlas, 6(Özel Sayı)/2018: 13-28.

TÜRER, Celal (2015). Ortak Yaşamlar Ortak Ölçütler, Ortak Yaşama Kültürü ve Felsefesi, haz. Celal Türer. Ankara: Türk Felsefe Derneği Yayınları.

YEŞILÇAYIR, Celal (2016). "Sı ğınmacılar Hakkındaki Ön Kabulleri Belirleyen Etmenler Üzerine Eleştirel Bir Değerlendirme”, Kutadgubilig Felsefe-Bilim Araştırmaları, 32: 121-138.

YEŞILLÇAYIR, Celal (2017). Ebedi Barış, Pax Romadan Birleşmiş Milletlere, İstanbul: Tezkire Yayınları.

\section{Online Kaynaklar}

http://www.bpb.de/internationales/weltweit/innerstaatliche-

konflikte/54765/bildungsarbeit-und-friedenserziehung, Erişim Tarihi: 15.08.18.

http://egitimdeinsanhaklari.org/media/documents/08_05_2015_13_53_06237a.pdf,

Erişim tarihi: 15.08 .18 .

http://www.rpi-loccum.de/material/aufsaetze/theo_mokrosch, Erişim Tarihi 10.08.2018. 